\title{
GLANVILL ON THE COMMON LAW: LEX TERRAE AND IUS REGNI
}

\section{Max Radin $\dagger$}

Only English law has a Glanvill and, as has been said in the case of the Year Books, only in English speaking countries, should we have had to wait so long for an adequate edition. ${ }^{1}$ The publication of Professor Woodbine's Glanvill, ${ }^{2}$ therefore, should mark a period in Glanvill-studies and stimulate renewed interest in the early history of English law. It may confidently be stated that now for the first time we have a definitive text and that no one need hereafter concern himself with manuscripts or with any variant readings that are not in Professor Woodbine's apparatus criticus. ${ }^{3}$

It is not necessary to discuss the position of Glanvill in the history of our law. That we should have a book written by a first rate man at the time when most of the institutions of later law were still in a formative state but already recognizable, is a piece of quite undeserved good fortune. Everything in Glanvill is historically important. It is regrettable in the highest degree that he was not aware of that fact. If he had been, statements based on his use of terms could be far more confidently made. ${ }^{4}$

But under all circumstances, although Glanvill was a man of affairs and neither a philologist nor an historian, the significance of phrases in legal documents and legal discussion was well enough known to him. We may therefore profitably investigate whether the use of certain expressions permits some inferences about the concept of English law which was in the mind of this first professed writer on English law.

$\dagger$ A.B., I899, College of City of New York; LL.B., I902, New York University; Ph.D., I909, Columbia University; professor of law, University of California; author, HANDBook of RoMAN LAW (I927) ; contributor to legal periodicals.

${ }^{2}$ One cannot too frequently echo Maitland's reproach to English and American lawyers, I Poliock \& MajtLand, History of ENGish LAW (2d ed. IgII) xxxv, repeated and emphasized by Bolland, Manual of Year Book Studies (I925) 34.

${ }^{2}$ Glanvill DE Legibus et Consuetudinirus Regni Angliae. Edited by George E. Woodbine. New Haven: Yale University Press, 1932, ix, 306.

${ }^{3}$ The only previous important discussion of Glanvill's text is by Maitland himself, Glanville Revised (I892) 6 HaRv. L. Rev. I.

The question of whether Glanvill himself wrote this treatise is not important for our purposes. Maitland (I Pollock \& MAITLAND, op. cit. supra note I, at I64) suggested that it might have been the work of Hubert Walter, Glanvill's kinsman, afterwards justiciar and Archbishop of Canterbury, a suggestion a little more strongly made by T. F. T. PLuckNeTr, A Concise History of THE COMMON LAw (1929) 19, 179. The denial of Glanvill's authorship is quite independent of the ascription to Hubert, which rests on a reference in BRACTON, De Legraus et Consuetudinibus Angliae f. i88b. Cf. I Pollock \& Maitzañd, op. cit. supra note $\mathbf{I}$, at $\mathrm{r} 64, \mathbf{n}$. 5. It is presented by Maitland only as a suggestion. Some doubt is cast on it by the fact that in one of the manuscripts of Glanvill, $\mathcal{Z}$, ascribed by WoopBxNE, op. cit. supra note 2 , at 20,220 , to the thirteenth century, there is a reference to $H$. Waiteri (WoodBINE, op. cit. supra note 2, at 92, n. 77). If Hubert had been known by Bracton to be the author of the treatise-an assumption on which Maitland's conjecture depends-a writer of nearly the same time would not have supposed that "Glanvill" was citing Hubert. 
The title of the book is Tractatus de legibus et consuetudinibus regni Anglia. The expression legibus regni et consuetudinibus occurs in the prologue. And it is further apparent that the two words leges and consuetudines are in this prologue treated as a hendiadys. The term, leges Anglicance, includes them both. But leges and consuetudines are none the less not synonymous. Leges is the more general term and within it might be included not merely consuetudines-although these formed the main content of the notion-but conceivably other determinations which in fact had the force of law.

That Glanvill had any juristic theory in a sense that would pass muster among professors of jurisprudence might be a little difficult to establish, but that he entertained no concepts about the nature and source of law is hardly likely. He surely knew the Institutes of Justinian and not merely some school-boy summary of them ${ }^{5}$ and it is rather unlikely that he was wholly unaware of canonical and scholastic disputations on these and kindred subjects. Theory and practice were generally merged in a society in which military, ecclesiastical, administrative and judicial functions were frequently the task of one man, who had in addition to justify his assumptions of authority against the jealous scrutiny of rival claimants. And we need merely glance at any political controversy of the time to see how every practical dispute would be placed, as far as possible, on a basis as broad and high as Infinity itself.

What phrases does Glanvill use besides leges et consuetudines when he wishes to refer to something more than a particular provision or a local custom? We find ius et consuetudo regni, ius regni, lex terre. To examine them, it may be of value to list all the relevant passages with an English version. ${ }^{6}$

\section{Ius regni}

I. Title. [Woodbine, p. 23] Institice gubernacula tenente illustri viro Ranulfo de Glanvilla iuris regni et antiquarum consuetudinum eo tempore peritissimo.

"While the helm of justice was held by the illustrious Ranulph de Glanvill, who was at that time more conversant than any other man with the law and the ancient customs of the realm."

2. Preface. [W. p. 24] Leges autem et iura regni scripto universaliter concludi nostris temporibus quidem omnino impossibile est.

"However, as far as our times are concerned, it is quite impossible for the various forms of law of the realm to be completely committed to writing."

I I Pollock \& Marrland, op. cit. supra note I, at 165 . Phrases in Glanvill that echo the Institutes are not confined to the trite phrases mentioned there, ibid. $\mathrm{n}$. I.

- The translation is in most cases a paraphrase. No attempt has been made to give an archaic tone to the version. Archaic is exactly what Glanvill was not in the eyes of the persons for whom he wrote. 
3. Lib. vii, c. I [W. p. 99] Magna quidem iuris dubitatio et virorum iuris regni peritorum disceptatio super tali causa in curia domini regis quandoque evenit vel evenire potest super hoc, scilicet quis isti de iure succedere debeat et possit.

"Indeed sometimes a serious legal question and a controversy bebetween men conversant with the law of the realm arises in such a case, or one may arise; on this point, to-wit, who ought or may lawfully succeed him."

(The question refers to the succession of a deceased son, a grantee of his father and seized in his surviving father's lifetime.)

4. Lib. vii, c. I [W. p. 99] . . . quia generaliter verum est secundum ius regni quod nemo eiusdem tenementi simul potest esse heres et dominus.

"Because in general it is true according to the law of the realm that no one can at the same time be heir and lord of the same tenement."

5. Lib. vii, I [W. p. I02] . . tunc secundum ius regni Anglic primogenitus filius patri succedit in totum.

". . . then according to the law of the realm of England, the firstborn son succeeds his father in the whole estate."

6. Lib. vii, I 5 [W. pp. III and $\mathrm{I} \mathrm{I} 2]$. . . vel hereditatem de iure regni petere potest.

"Nor may he claim the inheritance by the law of the realm."

(More fully given in No. I6 infra.)

7. Lib. vii, c. I6 [W. p. II2] Heredes quoque ipsius hac eadem. de causa exheredantur secundum ins regni et ad dominum vel dominos revertetur hereditas.

"Further his [sc. the usurer's] heirs for this same reason are disinherited according to the law of the realm and the inheritance will return to the lord or lords."

8. Lib. vii, c. I7 [W. p. II4] Preterea si quis de felonia convictus fuerit vel confessus in curia, eo per ius regni exheredato, terra sua domino suo remanet esceta.

"Besides if anyone has been convicted of felony or has confessed guilt before the court, by the law of the realm he is disinherited and his land is escheated to his lord."

\section{Ius et consuetudo regni}

9. Lib. ii, c. 3 [W. p. 59] Et quidem secundum ius et consuetudinem regni antiquam non licet nisi filium suum legitimum.

"And indeed according to the law and the ancient custom of the realm, it may be no one but his legitimate son."

(The reference is to a substitute champion.)

Io. Lib. iii, c. 4 [W. p. 72] Et quidem ita fiet secundum ius et consuetudinem regni, quia si alius terram ipsam vel saisinam ipsius terre propter defaltam warranti sui amittit, warrantus inde ei tenebitur ad competens escambium. 
"And indeed it will be so done in accordance with the law and custom of the realm, because if some one else loses the land itself or the seisin of the land because of a failure of warranty, the warrantor will then be held to provide a suitable land in exchange."

Ir. Lib. v, c. 5 [W. p. 86] . . posset enim tunc a domino suo secundum ins et consuetudinem regni ad vilenagium revocari, quia omnia catalla cuiuslibet nativi ita intellunguntur in potestate domini sui...

"He might then in accordance with the law and custom of the realm be reduced by his lord to villainage, because all the chattels of a serf are in so far understood to be in the power of his lord."

I2. Lib. vi, c. Io [W. p. 92] Heres igitur summonitus si nec venerit etc. . . . qualiter distringi debeat vel possit de iure et consuetudine regni quari potest.

"If an heir does not come when summoned, it may be asked how he ought or may be attached by the law and custom of the realm."

I3. Lib. vii, 5 [W. p. 105] Quicquid antem diversarum patriarum consuetudines super hoc teneant, secundum iura regni non tenetur quis in testamento suo alicui persone precipue nisi pro voluntate sua aliquid relinguere; libera enim debet esse cuinsque ultima voluntas, secundum has sicut et secundum alias leges.

"Whatever the customs of various communities may hold on this point, no one according to the laws of the realm is required to leave anything to any one person more than to another, except as he wishes; for the will of any person should be free according to our laws, just as in accordance with other systems of laws."

I4. Lib. vii, I2 [W. p. I09] Quia sine dominorum dispositione vel assensu mulla mulier heres terre maritari potest, de iure vel consuetudine regni. Unde si quis filiam vel filias tantum habens heredem, illam vel illas in vita sua sine assensu domini sui maritaverit, inde inste secundum ins et consuetudinem regni perpetuo exheredatur.

"Because no woman who is heir to land can be married without the direction or assent of their lords, by the law and custom of the realm. Hence if anyone has only a daughter or daughters as heir and marries her or them in his lifetime without the assent of his lord, then properly according to the law and custom of the realm, he is forever testamentarily incapacitated."

I 5. Lib. vii, I2 [W. p. IIo] Non enim videtur quod debeat ideo dotem suam amittere cum maritus suns inde mullum homagium waranto suo de iure et consuetudine regni facere debeat.

"For it does not seem right that a woman should lose her dower for the sole reason that her husband is not bound by his warranty according to the law and custom of the realm to do homage [for the dower-land]."

I6. Lib. vii, c. I5 [W. pp. I I I and II2] Et quidem licet secundum canones et leges romanas talis filius sit legitimus heres, tamen secundum ius regni et consuetudinem mullo modo tamquam heres in hereditate sustinetur, wel hereditatem de iure regni petere potest. 
"And as a matter of fact, although according to the canons and the Roman Law such a son is the legitimate heir, yet according to the law and custom of the realm he is in no way to be kept as heir in his inheritance nor can he claim the inheritance by the law of the realm."

\section{Lex terre}

I7. Lib. ii, c. 3 [W. p. 6o] Finito autem duello pana sexaginta solidorum imminebit victo nomine recreantise [var. recreantis] et preterea legem terre amittet. . . .

Si vero super hoc convictus et per duellion victus fuerit, tunc domimus suns loquelam suam amittet et ille victus omnem legem terre amittet, scilicet, quod de cetero in curia numquam admittetur ut testis ad dirationationem pro alio per duellum de cetero faciendam.

"After the battle is over, the loser who has cried craven is faced with the penalty of sixty solidi and besides will lose his lex terre. . . .

"But if he is attainted for this and is beaten in battle, then his lord loses his plea and the one beaten in battle loses all the lex terra; to-wit, he will never thereafter be admitted as a witness in court [nor] be allowed to make proof by combat for another person."

I8. Lib. ii, c. I9 [W. p. 69] Insuper autem de cetero legem terre amittentes perpetuam infamia notam inde merito incurrent. Quce pana ideo recte constituta est, ut quoslibet ab illicita prastatione sacramenti in tali causa coerceat similitudo supplicii.

"Besides they [sc. the attainted assize] lose thereafter the lex terrce and justly receive a perpetual brand of infamy for their conduct. This punishment is rightly established with this end in view that the improper taking of an oath on the part of any person may in such a case be restrained by assimilating the punishment to that of perjurers generally."

I9. Lib. v, c. 5 [W. p. 87] Quia si prius nativus ad libertatem hoc modo productus contra extraneum aliquem ad dirationationem faciendam produceretur in curia, vel ad aliquam legem terra faciendam, posset inde iuste amoveri.

"But if before this, a serf presented in this way, is presented in court to make a proof against a stranger or to make some form of lex terre, he may be lawfully removed."

20. Lib. vii, I7 [W. p. II4] Cum quis vero per legem terrce fuerit utlagatus et postmodum beneficio principis paci restitutus, non poterit ea ratione hereditatem . . . nisi ex misericordia ipsius domini et beneficio... recuperare.

"When anyone has been outlawed by the lex terrce and thereafter by the favor of the sovereign, restored to the public peace, he will not for that reason alone be able to recover his inheritance . . . except as a personal act of mercy and favor of his lord."

21. Lib. x, c. 3 [W. p. I34] Cum quis itaque aliquid tale crediderit, si plus eo receperit, usuram facit, et si in tali crimine obierit, damnabitur tamquam usurarius per legem terre, unde superius dictum est et plenius.

"When any person therefore has made such a loan, if he gets back more than this loan, and if he dies while this accusation is pending, he 
will be condemned by the lex terre as a usurer, on which subject we have spoken above, more fully."

22. Lib. xiv, 2 [W. pp. $\mathrm{x} 76$ and $\mathrm{x} 77$ ] Placitum de occultatione inventi thesauri fraudulosa ubi certus apparet accusator modo et ordine pradicto solet tractari. $O b$ infamiam autem non solet aliquis iuxta legem terre per legem apparentem se purgare, licet aliter per assisam fieri posset, nisi prius convictus fuerit vel confessus in curria aliquod gemus metalli in loco proposito invenisse et recepisse. Si enim super hoc convictus fuerit, presumptione contra eum faciente, tenebitur se purgare per legem terra se nihil amplins ibi invenisse vel recepisse.

"The plea concerning the fraudulent concealment of treasure-trove, when a specific accuser appears, is generally conducted in the manner and order stated above. On mere rumor it is not usual for anyone to clear himself by waging law in accordance with the lex terre . . . although on the other hand, he may do so by the assize-unless he was first attainted or unless he has confessed that he has discovered and taken some kind of precious metal in the place in question. If he is attainted on this point, and the general appearance is against him, he will be required to clear himself by the lex terra that he neither found nor took anything more there."

If we examine the instances numbered I-8, containing ius regni alone, it will be seen that, besides the general references $I-3$, the reference in 4 is to a general rule of feudal tenure, 5 to primogeniture, 6 to the incapacity of bastards, 7-8 to escheats. The long phrase ius et consuetudo regni, refers in 9 to trial by battle, Io to warranty of tenure, I I to the right of a lord over his serfs, I 2 to the procedure in the royal court, I 3 to freedom of bequeathing chattels, I 4 to the feudal right of maritagium, I 5 to homage and its effect on dower, 16 to the incapacity of bastards.

That is to say, in all these cases, we are dealing with a feudal system fully organized and involving an interrelation of persons of varying status from the nativus to the sovereign; in this case, the king. The ius regni, or the ins et consuetudo regni, refers to specific elements in a regnum, as understood by feudal lawyers, that is, the complex of claims and privileges which bound together all the subjects of a rex to him and to each other through direct or indirect grant from him.

Now if we examine numbers $17-22$, even if we put out of our minds as completely as we can the interminable controversy concerning lex terre in Magna Carta, we shall see that we are in a different sphere. The term cannot be translated "law of the land" without being unintelligible, and its exact equivalent is sufficiently dubious to make it necessary to leave it untranslated for the present. In $I 7$ and $\mathrm{I} 8$, the phrase is "to lose one's lex terre", which in I7, Glanvill considerately explains for us. The man who has lost lex terre is incompetent as a witness or as a champion in trial by 
battle. The witness, of course, is a compurgator, not the modern witness, but it is well to note that suffering either incapacity is to lose lex terre. In 20, an outlaw, utlagatus, has his status determined by the lex terra. In 22 , once more the reference is apparently to compurgation.

In number I9, the phrase "aliqua lex terre" is added to ordinary proof, dirationatio, "deraigning", and can mean nothing but the capacity to make proof in some other way than the usual form of compurgation. In 2I, however, there is a specific reference to the condemnation of usurers by the lex terre. Glanvill refers us to a previous fuller discussion of this point, which turns out to be $l i b$. vii, c. I6. There it is declared unreservedly that the usurer forfeits all his goods and chattels to the king, and that this is established only after the usurer's death by a special inquisitio regia-per duodecim legales homines de visneto . . . nothing more or less than what we should describe as a trial by jury, but one that still maintains its original function of asserting a royal prerogative.

This is in sharp contrast with the lex terre of the other passage, which dealt entirely with a personal privilege of a subject and one which once by its terms utlagatus and in the other cases by its substance, compurgation, is rooted in an ancient and pre-Norman status. Except for this one disturbing passage, we should be able to take ius regni as the law which owes its existence in England to a developed feudalism and therefore to the Norman conqueror. It is the law which the king will enforce either in his courts or in any other courts as far as he may control them. Against this, it would be possible to contrast the lex terre as something which in Glanvill's mind, had its roots in the soil, a body of immemorial privileges that antedated the regnum as the Normans understood it. ${ }^{\top}$ The contrast may indeed be made, but it would require the reservation that lex terre might be used occasionally in a sense indistinguishable from what seems to be the implication of ius regni.

As a matter of fact, however, if we look at 7 and $2 I$ together, it is evident that the ius regni is specifically associated with the disinheritance of the usurer's heirs while the lex terrce refers to the condemnation of the dead usurer and the forfeiture of his chattels. That is not much of a difference, but it may be well to keep it in mind. What is clear, however, is the fact that as far as the usurer himself is concerned, his posthumous status is declared to be established by the lex terre.

It is therefore not inappropriate to cite a passage from the Laws of Edward the Confessor, as published in Liebermann, Gesetze der Angelsachsen. $^{8}$

'We must therefore qualify somewhat the statement of Professor Plucknett (op. cit. sipra note 4, at 179) that Glanvill completely ignores "all the tangled masses of local custom which certainly were still in force; . . . most of the surviving traces of pre-conquest law are likewise absent from his book."

${ }^{8}$ I LIEBERMANN, Gesetze der ANGelsachsen (Ig03) 668a, 37. 
De usurariis. Usurarios etiam defendit rex Eadwardus, ne esset aliquis in regno suo: et si aliquis inde probatus esset, omnes possessiones suas perderet et pro ex lege haberetur.

"On Usurers. King Edward likewise forbade usurers, that there be none of them in his kingdom: and if anyone be proved guilty of it, he was to lose all his possessions and be held an outlaw."

The Laws of the Confessor is more than suspect. It is likely that the characterization of it by Maitland as "private work of a bad and untrustworthy kind" " must be allowed to stand. That it is a statement of AngloSaxon laws declared by juries summoned for that purpose by William is of course untenable. Liebermann submitted the book to an exhaustive analysis in his edition and later in I9I6 in the third volume of his great work, he gave a revised introduction and evaluation of it (pp. 339-342). One thing, however, is evident. It is not, like the Mirrour of Justices, an irresponsible and unscrupulous screed. The author doubtless lied in the interests of his order and on any controversial point, his evidence is probably not as good as that of almost any other document of the period, but Dr. Liebermann is far from rejecting the Leges Edwardi as an historical source. "Der historische Wert," he tells us ${ }^{10}$ "des Schriftchens ist im Verhältnis zum Umfang bedeutend." For a number of matters, found here and here only, Liebermann accepts the evidence of the collection as authoritative.

It is quite certain that when the book was written, the deceased usurer's chattels were forfeited in England. But this usage certainly did not come from Normandy where it was unknown or from any of the fiefs of the Norman-Angevin line. ${ }^{11}$ We need not accept the statement of the Leges Edwardi that it was the Confessor who established this, but it seems likely enough that the rule was pre-Norman. In other words, it may well be a

${ }^{\circ} \mathrm{I}$ Pollock \& MartLand, $o p$. cit. supra note $\mathrm{I}$, at I03.

${ }^{10} 3$ LIEBERMANN, GEsetze DER ANGeISACHSEN (I9I6) 342, Io.

11 The disposition of a usurer's property is also set forth in the Dialogus DE Scaccario (Hughes, Crump, Johnson ed. II, $x, b, 136$, with the elaborate note at $224-225$. A discrepancy is declared by the editors to exist between Glanvill and the Dialogue, but if it does, it is probably not in regard to the realty, since Glanvill is far from saying that the land escheats or is forfeited. The difference is in the statement "sive testatus sive intestatus" of Glanvill as compared with the simple si intestatus of the Dialogue. But the qualification in the Dialogue really removes the discrepancy. The editors seem to cite 2 PoLLOCK \& MAITLAND (I895) 354 for the case of Hamo Blund "who died intestate and is commonly accused of having lent his money on usury". Chron. Jocerint DE Brakerond (Camden Soc. p. 67). There is some confusion here. The reference to PoLLOCK \& MAITLAND should be to page 357 (Ist ed. at 355 ), and the statement occurs neither in PoLLOCK \& MAITLAND nor in Jocelyn. Hamo was not charged with usury, but it appeared merely that he had deliberately chosen to die intestate as to most of his property. Perhaps the editors have confused Hamo Blund with Adam Blund, who in 3I Henry II accounted to the exchequer for the "chattels of an usuress", Madox, History of THE ExcheQuer (I769) x, $\$ 8$, p. 237, n. r. There is an English translation of Jocelyn by L. C. Jane (I907), in which the Blund incident is told on P. I44.

It will be noted that the entire passage "Heredes ... hereditas" of Glanvill [W. p. II2, text supra no. 7] is omitted by Mss. R and V. Both manuscripts belong to the better (beta) tradition, [W. pp. I9-2I] but are not the best of their group. It seems reasonable to assume that the omission indicates either a change in the law on usurers between Glanvill and the date of $R$, or a difference of opinion on what the law was. 
fact that the dead usurer was dealt with in pre-Norman times just as the Leges Edwardi declare, to wit, as outlaw, exlex, utlagatus. And if he was exlex, utlagatus, the expression per legem terre is technically correct, as is shown by 22 and by the various passages in Bracton where per legem terre is closely associated with utlagatio.

This brings 2 I within the distinction sought to be established and makes it possible to assert for Glanvill a conscious and consistent discrimination between ins regni and lex terre.

This ius regni as well as the fuller form ius et consuetudo regni is contrasted with the canon law on the subject of legitimation and with local custom on the subject of primogeniture. It is further, in regard to liberty of testation, declared to be in accord with other systems. It is, therefore, a system which already has certain characteristic rules, almost certain fixed principles. It is further a system which allows controversies to arise, so that its right to challenge a place at the side of the canons and the leges romance is not too preposterous.

The distinction between lex terrce and ius regni here sought to be made out, may throw a little light on the most famous crux of English constitutional history, the phrase per iudicium parium vel per legem terre of Magna Carta. Evidently the question cannot be fully discussed here. The dispute has raged furiously and except for the negative conclusion that iudicium parium is not trial by jury, no general agreement may be said to have been reached. The most important divergence on the subject of lex terre is between those who think of it as referring to compurgation and those who regard it as the practical equivalent of its literal translation, "law of the land" in the modern sense. ${ }^{12}$ Apparently the meaning here suggested for the phrase in its use in Glanvill has not been discussed. If it is used in Magna Carta, as it seems to be in Glanvill, it refers not to compurgation alone, but in general to any rule which could be ascribed to ancient preNorman days - which was attached to the soil itself, either any particular piece of it or to all of it.

One thing further is to be noted. A patent of May Io, I2I5, referring to the projected agreement between John and the barons, has frequently been cited in connection with the interpretation of the charter. John declares that he has granted his hostile barons, that no one will be condemned nisi per legem regni nostri vel per iudicium parium in curia nostra. ${ }^{13}$ The exact

${ }^{22}$ For a discussion of these much disputed words, $c f$. ADAMs, THE ORIGIN of THE ENGursh Constitution (Enlarged ed. I920) 242, and 262-274, n. D; VinogradoFf, MAGna Carta Comamenioration Essays (H. E. Malden's ed. IgI7) clause 39, at 78-95; and Powicke, Per Iudictum Parruar vei per Legem Terrae 95-I2I; McKechnie, Magna CARTA (I9I4) 375-395, c. 39. Cf. also, I Holdsworth, A History of ENGLISH LAw (3d ed. 1922$) 60-63$.

${ }_{23}$ The letter is generally quoted from RYMER's FoEDERA, $i$, I28. It is to be found, however, in a more authentic source, the Rotuli Litterarum Patentium, at page I4I-a reference I owe to my colleague, Professor W. A. Morris. 
words of the patent occur in the Charter with two significant changes. The words in curia nostra are omitted and per legem regni nostri is changed to per legem terre..$^{14}$

That the omission of the words in curia nostra is a deliberate change demanded and secured by the barons is unquestionable. They were not ready to admit that the judgment of their peers by which they might lose their lives or property must in every case be rendered in the presence and under the presidency of the king. ${ }^{15}$

May we make the same assertion for the change of lex regni to lex terra? We assume of course that lex regni and ius regni are in this instance practically equivalent. May we assume that the suggestion of lex regni to the barons was of something which, being coextensive with the king's allegiance, was justiciable only in the king's courts? In that case, we can understand that the expression lex terre would carry with it a claim to immemorial privileges both against the king and against, it may be, their sub-vassals. It has been asserted ${ }^{16}$ that lex terre must be taken in a general sense, because compurgation or ordeal could take place only after a iudicium. But in case of outlawry-the almost classic example of a proceeding per legem terre, there was no iudicium because the defendant did not appear.

Once Magna Carta was established as the most important of English constitutional documents-and long before it was made into a fetish by Coke-the phrase per legem terrce could be taken to be the practical equivalent of ius regni, and doubtless was so taken. This was especially the case when the peculiar institutions dealt with by the lex terre, the ordeal, outlawry, compurgation, were either obsolete or obsolescent. By that time, however, the phrase lex communis had become definitely established.

In conclusion one may call attention to a significant phrase. Glanvill, lib. iii, c. 4 [W. p. 72] speaks of the ius et consuetudo curice in the matter of essoins. It is, in all strictness, a procedural matter, but we can see how the "custom of the court" is hard to distinguish from a "custom of the realm" which is only to be asserted in the king's court. We are far away, as yet, from any doctrine that the court either declares or makes the law. Still ius et consuetudo have already indicated a movement in that specific direction, and the curia domini regis in all its phases will soon assume an

14 The letter of Pope Innocent III to the barons (RYMIER's FoEDERA, i, I36) quotes the grant of John in the terms that John uses in the patent above mentioned and ignores the changed form in which these expressions actually appear in the Charter.

${ }^{15}$ As far as the meaning of $v e l$ is concerned, there is no doubt that the word is used in Medieval Latin where "and" is a better translation than "or". Maitland suggested that the mercantile and/or would be a proper equivalent. I PoLIOCK \& MAITLAND, op. cit. supra note I, at I73 n. 3. Professor Adams supposed that a disjunctive use of vel would give the king a choice between indicium parium and lex terrae, assuming that lex terrae meant a kind of procedure. ADAMS, op. cit. supra note 12, at 263. However, in classical Latin, vel gives the choice to the person addressed.

${ }^{10}$ ADAMs, op. cit. supra note 12, at 263. 
intuitional relation with the law of the realm to an extent met with nowhere else.

Of this Glanvill doubtless had no intimation. But of a "Common Law" in our sense-the law of England as such-he might have given no bad description, if he said it was the logical development of the ius regni, as distinguished from the lex terre.

Since we are dealing only with Glanvill, the later use of lex terre is not necessarily conclusive. But even in this later usage, it is probable that the distinction between lex terre and the common law proper, the ins regni, is maintained. The use of the phrase secundum legem terra in connection with outlawry, utlagatio, is frequent in Bracton, as commentation on Magna Carta have indicated. Besides the usual references to ff. $125^{-1} 32$, Professor Woodbine has been kind enough to call my attention to ff. $3 \mathrm{IIb}, 42 \mathrm{I}$, and 435. I am also indebted to him for references to the phrase in Bracton, serundum legem et consuetudinem Anglia, which is used of legitimacy ( $f$. $4 I 6$ ), age (f. $422 b$ ), and warranty (f. 423 ). It is noteworthy that about a very special English custom, but one established after the conquest, $i$. e., curtesy, the phrase regularly used in Bracton is secundum legem Anglice, not legem terre. ${ }^{17}$ In Bracton's Note Book, the phrases applied to curtesy are per consuetudinem regni, (case 266), secundum legem et consuetudinem regni, (29r, 487), secundum consuetudinem regni (3I9, 9I7), per legem Anglice, (4I3 in margin, II82). Once and once only, apparently, is the expression per legem terre used ( $\mathrm{I} 686$ ).

In spite of this single exception, it may surely be said that the phrase lex terre retains its special sense in much later times. In the early Year Books ley comune is already well-established, and is usually contrasted with some right under a statute. But lex terre, i. e., ley (lei) de terre also occurs, and usually in a highly specialized sense. So in Neville v. Rokele ${ }^{18}$ it is declared that the lei de terre required two summoners. The phrase is used in exactly the same situation in Ofheyne $v$. Staplegate. ${ }^{19}$ In Theyn $v$. Grendale, ${ }^{20}$ once more in connection with a summons, we read: "Et ceo de comune dreit et ley de terre", which is repeated by Hengham. ${ }^{21}$ Evidently comune dreit, which is used interchangeably with comune ley, is different from ley de terre, although it may have already come to include it. It may be said that the phrase per legem terre interpolated in the Leges Henrici, 8, I. in the $13^{\text {th }}$ century, ${ }^{22}$ quoted by Adams, ${ }^{23}$ is not inconsistent with the meaning here contended for.

${ }^{27} C f$. BRActon, ff. $437 \mathrm{~b}, 438,438 \mathrm{~b}$.

Is Y. B. I Ed. II-East. 8, I7 Selden Soc. 19 (1903). Facsimile in Bolland, Manual OF YEAR Book STUDIES (I925) I26.

${ }^{20}$ Eyre of Kent 6 \& 7 Ed. II, 27 Selden Soc. 6r (I912).

${ }^{20}$ Y. B. 4 Edw. II Trin. 3I, 42 Selden Soc. I30 (r925).

${ }^{21}$ HenghaM (Dunham ed. 1932) I3r.

$\approx$ I LIEBERMANN, op. cit. supra note 8 , at $554, \mathrm{n} . \mathrm{d}$.

${ }^{23}$ AdAMs, op. cit. supra note 12, at 267 . 